Jurnal Pendidikan Fisika
https://journal.unismuh.ac.id/index.php/jpf
DOI: 10.26618/jpf.v9i1.4499

\title{
The Development of Teaching Material Based on Science, Technology, Engineering, and Mathematics (STEM)
}

\author{
Abdul Rahman*, Kaharuddin Arafah, Muhammad Arsyad \\ Prodi Pendidikan Fisika, Pascasarjana, Universitas Negeri Makassar, Makassar, 90222, Indonesia \\ *Corresponding author: abdul10_rahman09@yahoo.co.id
}

Received: December 08, 2020; Accepted: January 19, 2020; Published: January 30, 2021

\begin{abstract}
This research is a development research that aims to describe a valid profile of STEM-based teaching material development, analyze students' responses to the development of teaching materials and analyze the effectiveness of STEM-based teaching materials to examine creative thinking skills. This research was conducted at SMAN 9 Makassar in class XI MIA 6 consisting of 32 students as respondents. STEM-based physics learning was carried out 5 times on static and dynamic fluid material. Learning activities contain four elements, namely science, technology, engineering and mathematics, and the STEM results made are making hydraulic bridges and simple mosquito sprays from used materials. The development model used was ADDIE which consists of analysis, design, development, implementation and evaluation. The ADDIE model is a development procedure carried out by producing a STEM-based physics learning product. The intended product is to produce a STEM-based physics teaching material, step-by-step. These steps are included in the teaching material that must be validated and ready to be used by the teachers in carrying out learning so that students can think creatively. The results showed the practicality of physics teaching material based on practical STEM. It was seen from the results of the responses of students and the responses of teachers who were in the very good category. Learning using STEM-based teaching materials is effective and can make students think creatively. This is shown in the fluency thinking indicator with a percentage of $74.58 \%$, the flexible thinking indicator $71.25 \%$, the original thinking indicator $81.56 \%$, and the elaborative thinking indicator $82.03 \%$, with an average percentage of $77.36 \%$ which is in the creative category.
\end{abstract}

Keywords: creative thinking, design learning, effective, practicality, STEM.

(C) 2021 Physics Education Department, Universitas Muhammadiyah Makassar, Indonesia.

\section{INTRODUCTION}

Science and technology are developing very rapidly. Students are required to be able to master various skills in order to be able to compete globally. The 21 st century is the age of knowledge, where information is widely spread and technology is increasingly developing. Preparation for the 21 st century requires special skills, namely 21 st century skills. According to Susilo (2015), teachers must be fully aware that the characteristics of 21 st century learning refer to efforts to enable students to master 21 st century competencies. This 21 st century competency is known as $4 \mathrm{C}$ (critical thinking and problem solving, 
creative and innovation, communication, collaboration) (Susilo, 2015).

The 21 st century learning is a learning transition where the currently developed curriculum requires schools to change the teacher-centered learning approach to studentcentered learning. In addition to the four characteristics of $21 \mathrm{st}$ century teaching, learning must also enable students to master digital literacy. Digital literacy consists of information literacy, media literacy, and ICT literacy (Sani et al., 2020).

The 2013 curriculum is one of the changes in the learning paradigm from conventional learning to one that activates students and trains students' creative thinking skills. The implementation of the 2013 curriculum aims to produce productive, creative, innovative, affective Indonesians through strengthening integrated attitudes, skills and knowledge. This curriculum emphasizes the involvement of students in the learning process actively in the learning process, so that students can acquire a form of direct experience and are trained to find out for themselves the various knowledge they are learning (Ali, 2020).

Creative thinking requires students to have the ability to solve problems, have various answers, have the ability to master a problem concept, convey ideas or ideas on a problem topic. Therefore, creative thinking is one of the abilities developed in the 2013 curriculum, so that creative thinking is very influential on learning outcomes where learning outcomes are usually influenced by students' understanding of a learning concept and the ability of students to solve a problem in the learning process (Cintia et al., 2018).

One of the efforts made in getting graduates to have the ability to relate the knowledge obtained to real life in the world of education is the use of integrative approach, namely the approach carried out using scientific disciplines. Science, technology, engineering, and mathematics (STEM) is a contemporary approach in the development of education that integrates more than one discipline. The integrated application of STEM indirectly requires teachers and students to think creatively. Because on the teaching process using STEM approach the students are asked to design a project therefore the student indirectly have to use their creative thinking to produce a product. Besides using an integrative approach, teachers are required to be creative in developing teaching materials. The teaching materials used by the teacher greatly affect the learning outcomes of students. In science learning, students are guided by the teacher to actively find their own understanding related to learning material.

The development of teaching materials must pay attention to the demands of the curriculum, meaning that the teaching materials to be developed must be in accordance with the curriculum. In the 2013 curriculum which refers to BSNP (Badan Standar Nasional Pendidikan) both content 
standards, process standards and graduate competency standards have been set by the government. The teaching materials used are completely left to educators as professionals (BSNP, 2006). Teaching materials are usually independent, meaning that students can learn independently because they are systematic and complete. However, in reality the current teaching material content is dominated by theory. Even though students need to understand and accept objectively, concretely and rationally towards learning, especially in learning physics. In addition, students do not participate in giving questions, answers that do not vary, always based on books.

In connection with the above statement, this condition also occurs in SMA Negeri 9 Makassar. Researchers have made preliminary observations on supporting books in terms of concept analysis, assignments and specification of objectives on certain materials. The researchers also observed the characteristics of students at the school. The supporting books used still have shortcomings. This creates difficulties to students to understand when learning. Students also do not develop their skills in making or designing a work. From the results of observations of students' creative thinking abilities from an average of four indicators has a percentage of $59.81 \%$, which is in the quite creative category. The lowest creative thinking indicator at the time of observation is the original thinking aspect with a percentage of $43.48 \%$. Meanwhile, the percentage of
$71.45 \%$ is the fluent thinking aspect. It can be seen in the original aspect where in learning students work on questions in one way only, tend not to give answers, rarely ask questions when there are questions to be done, and only hope from friends.

Based on this problem, the researcher tries to provide an alternative by making the teaching material function as a tool that makes it easy for students and teachers in the learning process so that they can improve their creative thinking skills due to the teaching material being developed. The teaching materials were developed with a STEM-based approach to fluid materials in an attractive, logical, systematic, innovative and easy to use manner.

\section{METHODS}

This type of research is called research and development (R\&D). This research learning development procedure adapts the ADDIE model development. The research design and development of STEM-based teaching materials carried out refers to the development of the ADDIE (Analysis, Design, Development, Implementation, and Evaluation) model proposed by Robert Maribe Branch (Sugiyono, 2017).

This study was conducted at SMA Negeri 9 Makassar. The tested subjects in this study were 32 students in the class of XI MIA 6. This research was conducted in the Odd Semester of the 2020/2021 Academic Year. 
In this study, the instruments used to collect data were: expert validation sheets, student response questionnaires, teacher response questionnaires and tests of students' creative thinking skills. The formula for analyzing content validity data by two experts uses the following construct validity (Retnawati, 2016).

$$
\mathrm{V}_{\mathrm{C}}=\frac{\mathrm{D}}{\mathrm{A}+\mathrm{B}+\mathrm{C}+\mathrm{D}}
$$

The scale used to determine respondents' responses is the Likert scale.

Table 1. Conversion of student and teacher response questionnaire scores

\begin{tabular}{lcc}
\hline \multirow{2}{*}{ Answer options } & \multicolumn{2}{c}{ Score } \\
\cline { 2 - 3 } & Positive & Negative \\
\hline Strongly agree & 5 & 1 \\
Agree & 4 & 2 \\
Neutral & 3 & 3 \\
Disagree & 2 & 4 \\
Strongly disagree & 1 & 5 \\
\hline
\end{tabular}

The processing of respondents' questionnaire scores was carried out by following the following stages.

$$
\mathrm{P}=\frac{\sum x}{\sum x_{i}} \times 100 \%
$$

Information:

$\mathrm{P} \quad=$ percentage of score

$\sum x=$ the total score of each item

$\sum x_{i}=$ total ideal score (highest score)

Calculating the percentage of total responses with the formula:

$$
\mathrm{P}_{\text {total }}=\frac{\sum \mathrm{P}}{n}
$$

Information:

$\mathrm{P}_{\text {total }}=$ percentage of total responses

$\sum \mathrm{P}=$ total percentage of score $\mathrm{n} \quad=$ number of items / statements

If the average score of the percentage of students' responses to STEM-based physics teaching material that has been developed is $\geq$ 61, it can be stated that STEM-based physics teaching material gives a positive response (Riduwan \& Sunarto, 2015). The assessment score for measuring creative thinking skills uses the following equation:

Rating score = $\frac{\text { The number of scores worked on }}{\text { The total score of the highest score }} \times 100 \%$

(4)

Table 2. Classification of students' creative thinking assessment

\begin{tabular}{cc}
\hline Percentage & Classification \\
\hline $81,25 \% \leq \mathrm{P} \leq 100 \%$ & Very creative \\
$62,5 \% \leq \mathrm{P}<81,25 \%$ & Creative \\
$43,75 \% \leq \mathrm{P}<62,5 \%$ & Fairly creative \\
$25 \% \leq \mathrm{P}<43,75 \%$ & Less creative \\
$0 \% \leq \mathrm{P}<20 \%$ & Very less creative \\
\hline
\end{tabular}

If the percentage of students is at $43.75 \% \leq \mathrm{P}<62.5 \%$, it can be said that students have thinking skills with a fairly creative category (Wiyanto \& Sulistiarmi, 2016).

\section{RESULT AND DISCUSSION}

This study was research and development-based. The development carried out was the development of STEM-based physics teaching materials using the ADDIE development model. The following section discusses the development of STEM-based teaching materials. 
A. Results of the development of STEMbased physics teaching materials

Referring to the ADDIE development model, the analysis stage is the initial stage. This stage is about carrying out an analysis of the learning carried out by the teachers at school, analysis of students to determine their creative thinking skills, concepts, goals and basic competencies. At this stage, it is found that each student has different thinking skills. Where the percentage of students is only at an average percentage of $59.81 \%$, which is at the level of creative thinking. This percentage is obtained by looking at the results of the students' questionnaires that are distributed in which there are four indicators including fluent, flexible, original and elaborative thinking. These results then become the basis for researchers in carrying out development to continue at the design stage.

The design stage is the stage in compiling a teaching material that is able to meet the learning needs of students by involving the concept of science, technology, engineering and mathematics in teaching materials on static and dynamic fluid material. Judging from the creative thinking abilities of students, one of the lessons that is able to make students think creatively is by using a STEM-based learning model.

The steps for STEM-based physics teaching materials are part of the development stage. In the teaching material, one basic competency was taken, namely the application of static fluid laws in everyday life and in the second teaching material the basic competency was chosen, namely applying the dynamic fluid principle in technology. The production of this material is made by involving all STEM components. The resulting product is able to design a hydraulic bridge prototype and a mosquito spray using the scientific concept of fluid.

At the development stage, the contents of the materials to be developed are typed using Microsoft office word. After the content components of the material have been made, they are printed so that they become STEMbased teaching materials that are ready to use. Meanwhile, the cover design is designed using Corel Draw. The STEM prototype I based teaching materials that have been made are theoretically validated by means of expert validation before being applied and tested.

In line with Sugiyono's point of view, which states that product revisions are carried out if errors or deficiencies are still found during the trial. Referring to the research results of this teaching material, there is no need for revision (Sugiyono, 2015). Therefore, STEM-based physics material is declared valid and effective in the learning process. Valid can be seen from the results of the expert validator in the very good category for each indicator and effective seen from the responses of students and the creative thinking test.

At this stage of development, one of the steps used is expert validation consisting of material experts whose data is taken regarding 
assessments, opinions and suggestions related to modules which include aspects of the feasibility of formats and components, feasibility of presentation and language feasibility of teaching materials that have been validated categorized as valid but still needs a little improvement (minor revision). Improvements are adjusted to the opinions, suggestions from material experts so that the teaching material developed becomes more relevant and worthy of being tested at a later stage.

The results of expert validation from two validators on average state that the prototype physics teaching material developed could be used with minor revisions. The results of the quantitative analysis show that physics teaching material is in the valid category with the consistency of internal responses (reliability) from the two experts using the Gregory test being in the strong relevance category with a value of $\mathrm{R} \geq$ 0.75 or declared relevant.

Based on the validator's suggestion, several revisions were made. The results of the revision of physics teaching materials theoretically by experts are stated to be valid and reliable and can be used for field trials to determine the response of students to physics teaching material and the effectiveness of its application. Furthermore, based on the development carried out, the teaching material is implemented as material for the development evaluation has been carried out.
This can be seen in the practicality based on the responses of students and teachers. Where student's responses and teacher responses are shared after participating in STEM-based learning. In other words, the students' response questionnaire was given at the same time as the written test at the end after STEMbased physics learning, and the teacher's response was given when all the student questionnaires had been completed.

In addition to practicality, the feasibility of the development that has been carried out can also be seen from the level of effectiveness. The effectiveness of this STEM-based physics teaching material is obtained by looking at the product or project made and the creative thinking ability test on two basic competencies. The basic competencies referred to are static and dynamic fluids, with each prototype being a hydraulic bridge and mosquito spray.

\section{B. Practicality of STEM-based physics teaching materials}

As explained above, the practicality of this STEM-based physics teaching material can be seen from the results of teacher responses and student responses.

1. Results of students' responses to teaching materials

Teaching materials that have been validated are then used in learning in the trial class. After the physics teaching material is applied in learning, at the end of the lesson, 
students are given a response questionnaire. The students' response indicators provided consist of four indicators, namely content, presentation, language and graphics. The highest average is in the content indicator. However, the assessment category for the 4 indicators is very good. This means that the response of students after participating in learning using STEM-based teaching materials is declared very good and gives a positive response. This is because the learning carried out has adjusted the needs of students and also because students are directly involved in designing a product from the material being developed so that students are able to develop their creative thinking skills.

2. Results of teacher's responses to teaching materials

Teacher's responses to physics teaching materials were obtained from four physics teachers with undergraduate and postgraduate educational backgrounds who responded directly to the STEM-based teaching material that had been made. The aspects that become the assessment are aspects of content, presentation, language and graphics.

The results of the teacher's response show that physics teaching material is easy to understand, presented integrated with STEM, attractive cover display, attractive and clear illustration of the images used and the language used in the teaching material is easy to understand, the sentences are simple, and can make students make a product and make learners think creatively.
In general, the response given by the teacher to physics teaching material was very good. Where the average percentage score from the teacher response questionnaire is $91.96 \%$ which is in the very positive category. The results of the very positive response of the teacher indicated that STEMbased physics teaching materials were very helpful for teachers in the learning process, especially in making physics projects.

Based on the above statements, it is stated that the practicality of STEM-based physics teaching materials has been implemented. The students and teachers give positive responses to the teaching materials. This is in line with Rahmatina et al.'s study, that found that the feasibility of STEM physics teaching materials assessed by media experts is in the feasible category, so it is concluded that STEM-based teaching materials can be used in the learning process in SMA / MA (Rahmatina et al., 2020).

\section{The effectiveness of STEM-based physics teaching materials}

The effectiveness of this STEM-based physics teaching material is shown in the assessment of learning outcomes after participating in learning for 5 meetings. The type of test given was a creative thinking essay test with 12 items. The test was distributed to 32 students of class XI MIA 6 SMAN 9 Makassar at the end of the meeting. The results show that the average percentage of indicators for creative thinking is $77.36 \%$ (creative category). Of the four indicators, 
there are two indicators that have been included in the creative category, namely the flexible thinking indicator and the fluent thinking indicator.

In addition, for the percentage of students based on their creative level, there were 5 students' scores who were in very creative thinking level with a percentage of $16 \%, 22$ students or $68 \%$ of the students' were in creative category, and there were 5 students $(16 \%)$ were in sufficient category. This means that the STEM-based physics teaching material applied to learning is said to be effective because the large percentage of students based on the indicator is $77.36 \%$ with the creative category.

In line with the research conducted by Almuharomah and colleagues, it is stated that the STEM physics module integrated with local wisdom "drum" to improve creative thinking skills is appropriate to be used as a companion to textbooks in schools and gets a good response from students. Students' creative thinking ability is known to have increased with an $\mathrm{N}$-gain of 0.92 high category (Almuharomah et al., 2019). Furthermore, the improvement of learning outcomes using the STEM-based Problem Based Learning model was stated by Irfana, et al. Who stated that the results of the feasibility test in terms of the feasibility of content, presentation, and language, amounted to $85.21 \%$ indicating that STEMbased LKPD to improve creative thinking skills very worth using. The readability test results of $89.66 \%$ indicate that the STEMbased LKPD is easy to understand. Based on large group trials, STEM-based LKPD can improve creative thinking skills, namely in the aspects of fluency, flexibility, elaboration, and authenticity which is marked by an increase in the pretest-posttest score (Irfana et al., 2019). Meanwhile, according to Sudiatmika's research shows that with the application of the Project Based Learning learning model with the STEM (Science, Technology, Engineering, and Mathematics) approach in the material of temperature and heat, it can improve learning outcomes in physics class X RPL 1 SMK Negeri 1 Negara students (Sudiatmika, 2020). Likewise, what was obtained from Parno's research, the results showed that the PjBL STEM class was in the high category as well as the students' responses were in the very good category (Yuliati et al., 2020).

According to Mardiyah's research, it also shows that students' creative thinking skills through the PBL model with the STEM approach on vector material have a good implementation and support the process of learning activities that are both effective and fun for students (Mardiyah et al., 2020). Rika's research says that based on the T test there is a significant difference, which means that there is an effect of STEM-based PjBL on students' creative thinking abilities (Rika et al., 2020). 
Based on these statements, it is concluded that STEM-based physics teaching materials have a positive impact on learning physics. This is evidenced by the responses of teachers and students who show good categories. In addition, this STEM-based physics teaching material is said to be effective by seeing the percentage of students' creative thinking based on indicators of $77.36 \%$.

\section{CONCLUSION AND SUGGESTION}

\section{A. Conclusion}

The profile of STEM-based teaching materials includes: (1) teaching materials consisting of science, technology, engineering and mathematics (2) teaching materials developed in accordance with the learning methods used (3) teaching materials developed contain experimental activities, tools and materials related to the concept of static and dynamic fluid material, (4) the developed teaching materials contain indicators that are in accordance with STEM (5) the teaching materials developed are subject to material analysis (6) the teaching materials developed are able to find their own concepts and can develop ability to think creatively in making projects, namely simple hydraulic bridges and mosquito spray. The feasibility of teaching materials based on expert judgment with very valid criteria.

STEM-based teaching materials are stated to be practical, in terms of student responses and teacher responses in the very good category. Thus, the STEM-based teaching materials developed can be used as a learning tool.

The effectiveness of STEM-based physics teaching materials, seen from the creative thinking ability test of students, is in the creative category, ranging from students not to thinking creatively to being very creative that students might achieve.

\section{B. Suggestion}

1. Teacher: the results of this study indicate that the application of physics teaching materials is very effective in the learning process so that it is hoped that the teacher can make this teaching material as a learning resource for students, besides that the teacher needs to make teaching materials for basic competency integrated with STEM-based learning.

2. It is hoped that the next researchers can develop and strengthen the results of this research by conducting further research on STEM-based physics teaching materials.

3. Researchers should be tested more in several different schools with different subjects to determine the level of effectiveness on a broader scale.

\section{ACKNOWLEDGMENTS}

Thank you to the Principal of SMAN 9 Makassar, Drs. Supardin, M.Pd, for providing facilities in completing this research. 
A. Rahman.M, K.Arafah, M. Arsyad | JPF | Volume 9| Number 1 | 2021 | 63 - 72

\section{REFERENCES}

Ali, M. (2020). Kendala penerapan kurikulum 2013 dalam pembelajaran fisika di SMA Kabupaten Kota Barru. Cendekia: Jurnal Ilmiah Pendidikan, $8(1), 55-64$.

Almuharomah, F. A., Mayasari, T., \& Kurniadi, E. (2019). Pengembangan modul fisika STEM terintegrasi kearifan lokal "Beduk" untuk meningkatkan kemampuan berpikir kreatif siswa SMA. Jurnal Berkala Ilmiah Pendidikan Fisika, 7(1), 1-10.

BSNP. (2006). Permendiknas RI No 22 Tahun 2016 tentang standar isi untuk satuan pendidikan dasar dan menengah. Jakarta: Departemen Pendidikan Nasional.

Cintia, N. I., Kristin, F., \& Anugraheni, I. (2018). Penerapan model pembelajaran discovery learning untuk meningkatkan kemampuan berpikir kreatif dan hasil belajar peserta didik. Perspektif Ilmu Pendidikan, 32(1), 69-77.

Dewi, M. S., Lesmono, A. D., Hadiyanto, \& Harimukti, A. (2020). Keterampilan berpikir kreatif menggunakan model PBL (Problem Based Learning) dengan pendekatan STEM pada materi vektor di kelas X MIPA 4 SMA Negeri 2 Jember. Jurnal Pembelajaran Fisika, 9(1), 44-49.

Irfana, S., Yulianti, D., \& Wiyanto, W. (2019). Pengembangan lembar kerja peserta didik berbasis science, technology, engineering and mathematics untuk meningkatkan kemampuan berpikir kreatif peserta didik. Unnes Physics Education Jurnal, 8(1), 83-88.

Mawarni, R., \& Sani, R. A. (2020). Pengaruh model project based learning berbasis STEM terhadap kemampuan berpikir kreatif siswa pada materi pokok fluida statis di kelas XI SMA Negeri 4 Tebing Tinggi T.P 2019/2020. Jurnal Inovasi Pembelajaran Fisika, 8(2), 8-15.
Rahmatina, Jannah, \& Annisa. (2020). Pengembangan bahan ajar berbasis science, techonology, enginering and mathematics (STEM) di SMA/MA. Jurnal Pendidikan Fisika dan Fisika Terapan, 1(1), 27-33.

Retnawati, H. (2016). Analisis kuantitatif instrumen penelitian. Yogyakarta: Parama Publishing.

Riduwan, \& Sunarto. (2015). Pengatur statistika untuk penelitian: pendidikan, sosial, komunikasi, ekonomi, dan bisnis. Bandung: Alfabeta.

Sani, R. A., Arafah, K., Aziz, I., Tanjung, R., \& Suswanto, H. (2020). Evaluasi proses dan penilaian hasil belajar. Bandung: PT. Remaja Rosdakarya.

Sudiatmika, I. K. (2020). Penerapan model pembelajaran project based learning dengan pendekatan STEM dalam upaya meningkatkan hasil belajar fisika peserta didik kelas X RPL SMK Negeri 1 Negara Tahun Pelajaran 2019/2020. Jurnal Widyadari, 21(1), 34-44.

Sugiyono. (2015). Metode penelitian dan pengembangan. Bandung: Alfabeta.

Sugiyono. (2017). Metode penelitian kuantitatif, kualitatif, dan $R \& D$. Bandung: Alfabeta.

Susilo. (2015). Curriculum of EFL teacher education and indonesian qualification framework: a blip of the future direction. Dinamika Ilmu, 15(1), 11-24.

Wiyanto, W., \& Sulistiarmi, S. (2016). Analisis kemampuan berpikir kreatif siswa kelas XI IPA pada mata pelajaran fisika SMA NEGERI SeKota Pati'. Unnes Physics Education Journal, 5(2), 95-101

Yuliati, L., Ndadari, I., \& Ali, M. (2020). Project based learning integrated stem to increase students' scientific literacy of fluid statics topic. Journal of Physics: Conference Series, 6(1), 23-26. 